\title{
Design and Simulation of Nozzle for Pure Water Jet Portable Cutting Tool
}

\author{
Razali Abidin, Mohamad Asmidzam Ahamat, John Paul, Al Imran, Tarmizi Ahmad, Hafizi \\ Nordin, Wan Hanif Wan Yaacob
}

\begin{abstract}
A pure water jet at subsonic speed provides an opportunity for application in cutting soft material with the advantage of not contaminating the workpiece. Inside the nozzle, water is flowing through various cross sections, which lead to pressure drop and loss of energy. This requires a nozzle with a design that causes minimum pressure drop. In this work, Computational Fluid Dynamics (CFD) and Finite Element Analysis (FEA) were used to analyse the flow through five different nozzles. For each nozzle, the pressures of $10 \mathrm{MPa}, 20$ MPa and $30 \mathrm{MPa}$ were applies at the inlet. For the inlet pressure of $10 \mathrm{MPa}$, the highest outlet velocity us $136.12 \mathrm{~m} / \mathrm{s}$ at the pressure of $9.261 \mathrm{MPa}$. The impact pressure at stand distance of $0.5 \mathrm{~mm}$ and $1.0 \mathrm{~mm}$ were $8.26 \mathrm{MPa}$ and $8.02 \mathrm{MPa}$, respectively. For this nozzle, the Factor of Safety for $10 \mathrm{MPa}, 20 \mathrm{MPa}$ and 30 MPa were 6.4, 3.2 and 2.961, respectively. The findings are relevant to the development of pure water jet cutting machine.
\end{abstract}

Index Terms: factor of safety, inlet pressure, nozzle, pure waterjet, outlet pressure

\section{INTRODUCTION}

In cutting process, mechanical related methods are exposed to excessive tool wear and significant increase in local temperature. A worn cutting tool requires higher cutting force and produces surface finish with poor quality that leads to higher operating cost due to additional energy consumption and higher rejection rate of parts. These issues could be eliminated by using cutting system that utilizes high pressure water jet. High-pressure water jets are widely used in various mechanical works such as in cutting, cleaning and surface treatment. The use of high-pressure water jet does not increase the local temperature of work piece, subsequently eliminate thermal distortion.

Cutting process using high velocity water stream with or without abrasive remove the material that is being cut through erosion. High-pressure water is forced to flow through a small hole, which converts the pressure into kinetic energy. This requires hard material such as tungsten carbide and hardened steel to withstand the high pressure and abrasive environment if the fluid is mix with abrasive particles. However, abrasive condition does not exist in pure

Revised Manuscript Received on September 14, 2019.

Razali Abidin, Centre for Defense Research and Technology, National Defense University of Malaysia, Kuala Lumpur, Malaysia.

Mohamad Asmidzam Ahamat, Universiti Kuala Lumpur, Kuala Lumpur, Malaysia.

John Paul, Universiti Kuala Lumpur, Kuala Lumpur, Malaysia.

Al Imran, Universiti Kuala Lumpur, Kuala Lumpur, Malaysia.

Tarmizi Ahmad, Centre for Defense Research and Technology, National Defense University of Malaysia, Kuala Lumpur, Malaysia.

Hafizi Nordin, Centre for Defense Research and Technology, National Defense University of Malaysia, Kuala Lumpur, Malaysia.

Wan Hanif Wan Yaacob, Centre for Defense Research and Technology, National Defense University of Malaysia, Kuala Lumpur, Malaysia. water jet cutting machine. Although pure water jet cutting machine is only relevant for the cutting of soft material such as meat. In this machine, it is common to pressurize the water to 1300 to 6200 bar that will flow through a hole with diameter of $0.18 \mathrm{~mm}$ to $0.4 \mathrm{~mm}$. A high velocity water stream is produced, approaching the speed of sound. For a lower pressure $(\sim 10 \mathrm{MPa})$, the velocity of water jet can reach up to $133 \mathrm{~m} / \mathrm{s}$ [1]. This water jet can cut one-inch polystyrene, $4 \mathrm{~mm}$ mounting board and 1-inch sponge.

Tungsten carbide is appropriate for operating with unfiltered water at the pressure below $140 \mathrm{MPa}$ ) [2]. Steel has the operating pressure like tungsten carbide but the water must be filtered to 25 micron or better. For operation with pressure that is higher than $140 \mathrm{MPa}$, sapphire can be used provided the water is filtered to 10 micron or better. The properties of these materials enable them to have a good wear resistance for filtered and unfiltered water [3].

This paper concerns the simulation of pure water nozzle for portable cutting tool. Five designs of nozzle were evaluated to determine the suitable material, velocity and von Mises Stress.

\section{DESIGN OF NOZZLE}

Five designs of nozzle (Fig. 1 to Fig. 5) were modelled in the software. Two materials were used for the nozzle, which are aluminum alloy (5052-H321) and stainless steel 309(for Nozzle 1 only). The mesh applied to nozzles is as shown in Fig. 6. Static simulation analysis was conducted to identify the stresses within nozzle due to the force or pressure of water. The yield criterion and the von-misses were observed to identify any possibility of failure, when the von-misses stresses exceed the yield point of the material. Static loading of $10 \mathrm{MPa}, 20 \mathrm{MPa}$ and $30 \mathrm{MPa}$ was applied to internal parts of the nozzle. The analysis of flow was done in Fluent, where the pressure and velocity were evaluated. 


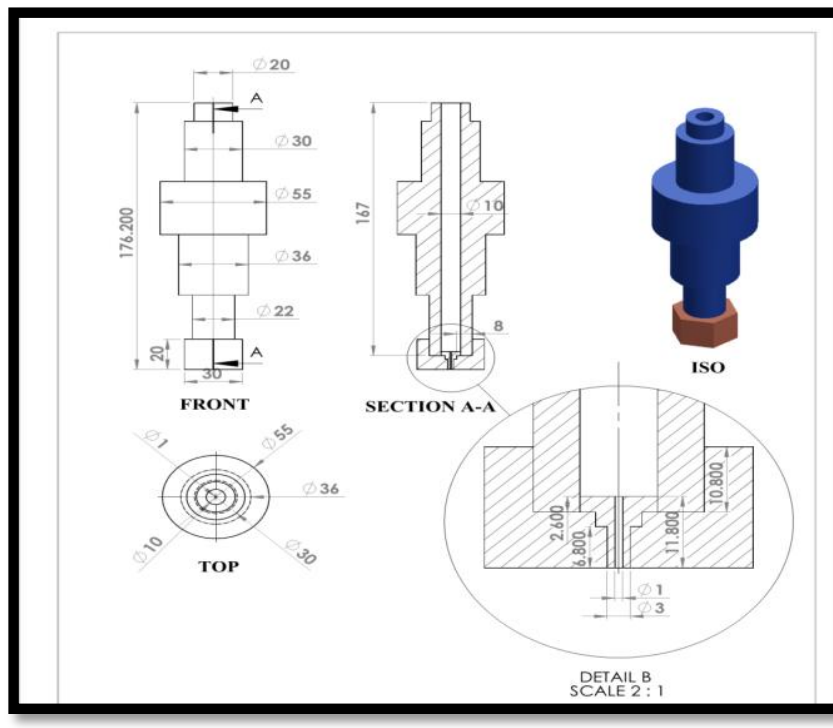

Fig. 1: Geometry of Nozzle 1

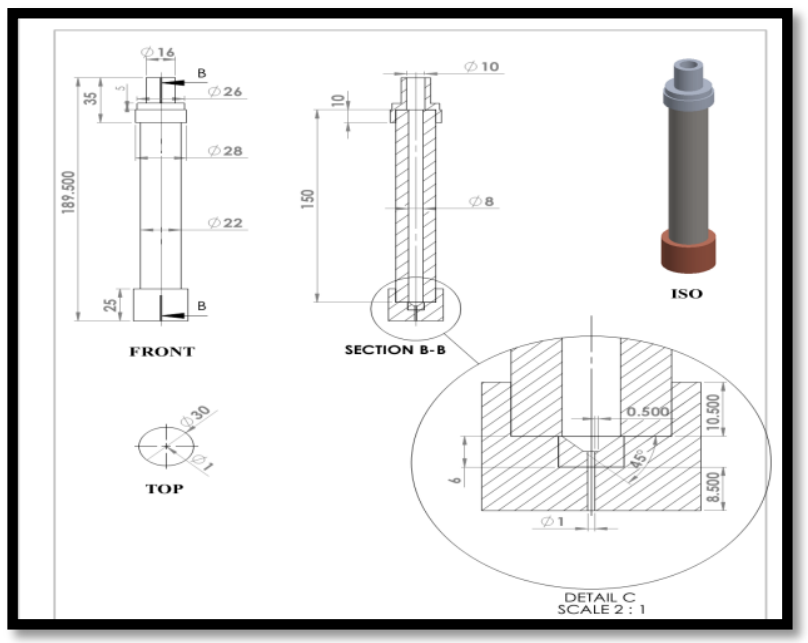

Fig. 2: Geometry of Nozzle 2

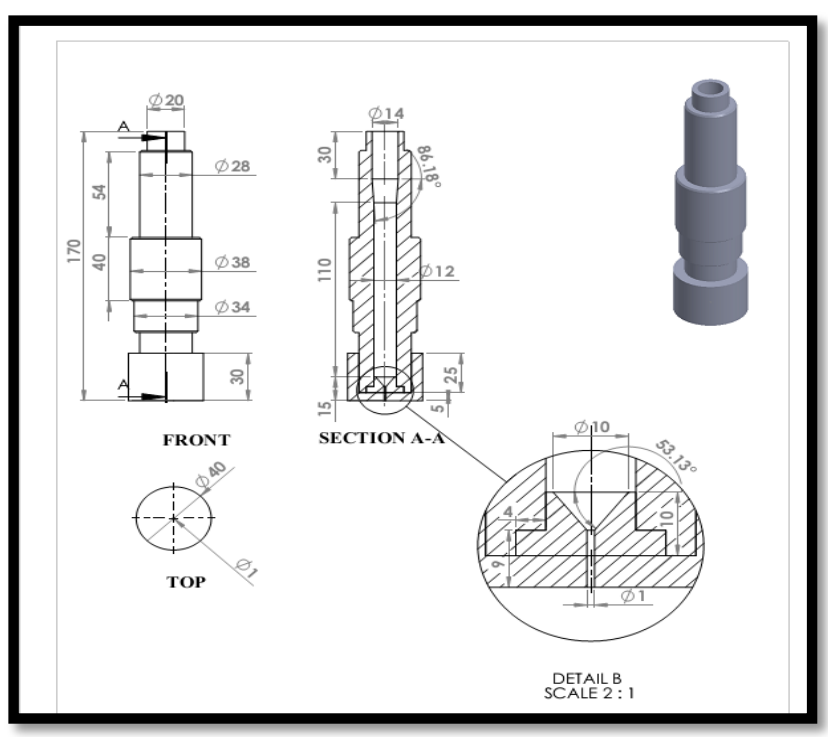

Fig. 3: Geometry of Nozzle 3

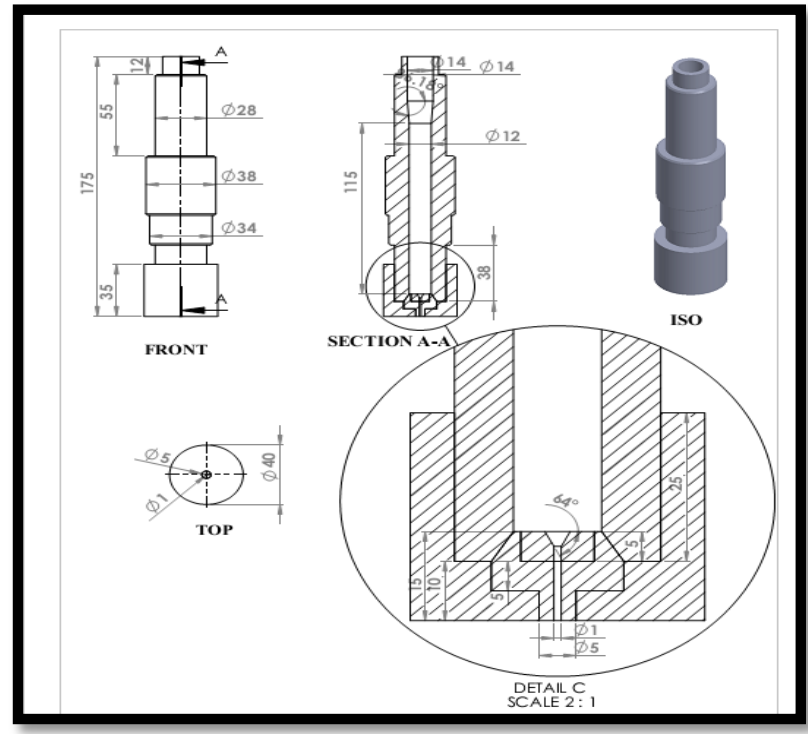

Fig. 4: Geometry of Nozzle 4

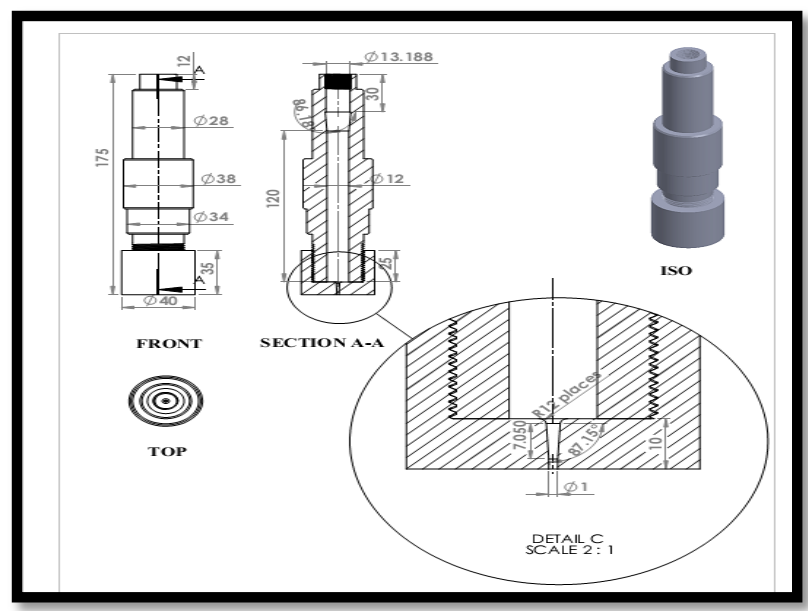

Fig. 5: Geometry of Nozzle 5

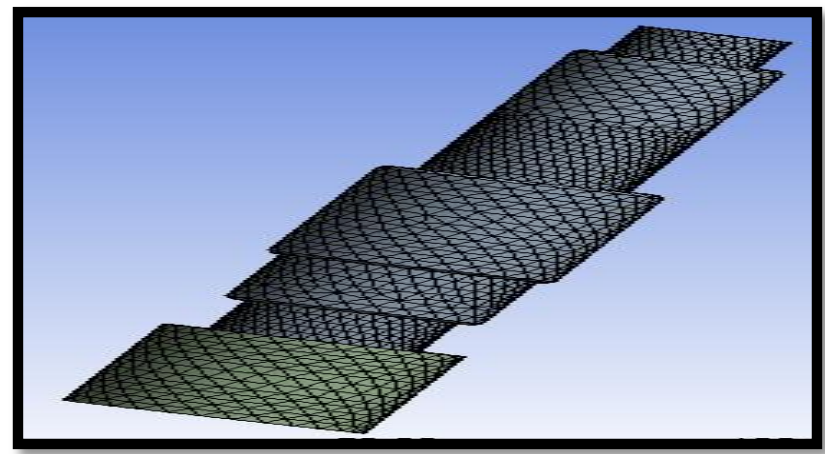

Fig. 6: Meshing of nozzles assembly parts

\section{RESULTS AND DISCUSSION}

Table 1 shows the parameters of simulation and results obtained for geometries of nozzles at various pressure and stand distance. For Nozzle 1, aluminum alloy (5059-H321) and stainless steel 309 were used. In general, pressure impact increase as the inlet pressure increase. The stand

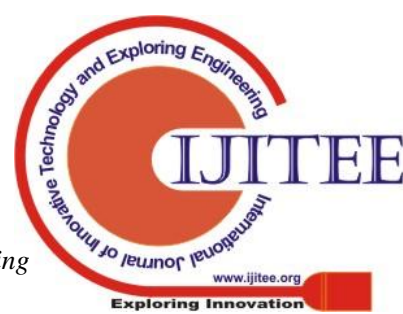


distance of $0.5 \mathrm{~mm}$ has higher pressure impact compared to $1 \mathrm{~mm}$ stand pressure. The Factor of Safety decreases as the inlet pressure increase with lowest of 1.9. For the average velocity, it does increases at higher inlet pressure.

The average outlet velocity for all types of nozzle is increases as the inlet pressure increases (Fig. 7). Nozzle 5 has the highest average outlet velocity for every inlet pressure. The ratio of average outlet velocity is as expected from the general energy equation, where the $30 \mathrm{MPa}$ produce a velocity of $\sim 1.7$ times of the velocity of $10 \mathrm{MPa}$. This shows that the pressure drop within the nozzle is less significant at these pressures for all types of nozzle.
The impact pressure for $30 \mathrm{MPa}$ inlet pressure is $\sim 3$ times higher than the impact pressure of $10 \mathrm{MPa}$ (Fig. 8). As the average outlet velocity, Nozzle 5 produces the highest impact velocity for all initial pressures. The impact pressure is affected by the stand distance. For the stand distance of $0.5 \mathrm{~mm}$ (Fig. 9), its impact pressure is about 3\% higher than the impact pressure for $1.0 \mathrm{~mm}$ stand distance (Fig. 10), for the same inlet pressure. There is no effect of stand distance on average outlet pressure.

Table 1: Parameters and results of simulation

\begin{tabular}{|c|c|c|c|c|c|c|c|c|c|c|}
\hline $\begin{array}{l}\text { Nozzle } \\
\text { Design }\end{array}$ & Materials & $\begin{array}{l}\text { Inlet } \\
\text { Pressure } \\
\text { (MPa) }\end{array}$ & $\begin{array}{l}\text { Max Von } \\
\text { mises } \\
\text { Stress } \\
(\mathrm{MPa})\end{array}$ & $\begin{array}{l}\text { Total } \\
\text { Deformatio } \\
\mathrm{n}(\mathrm{mm})\end{array}$ & $\begin{array}{l}\text { Safety } \\
\text { Factor }\end{array}$ & $\begin{array}{l}\text { Average } \\
\text { Velocity } \\
(\mathrm{m} / \mathrm{s})\end{array}$ & $\begin{array}{l}\text { Total Pressure } \\
\text { (MPa) }\end{array}$ & $\begin{array}{l}\text { Nozzle } \\
\text { Design \& } \\
\text { Material }\end{array}$ & $\begin{array}{l}\text { Stand } \\
\text { Distanc } \\
\mathrm{e}(\mathrm{mm})\end{array}$ & $\begin{array}{l}\text { Pressure } \\
\text { Impact } \\
(\mathrm{MPa})\end{array}$ \\
\hline \multirow{6}{*}{1} & Aluminum Alloy (5059-H321) & 10 & 28.111 & 0.0017231 & 9.9606 & 105.547 & 5.63569 & \multirow{6}{*}{$\begin{array}{l}\text { 1- For } \\
\text { Aluminu } \\
\mathrm{m} \text { Alloy } \\
(5059- \\
\text { H321) } \\
\text { and } \\
\text { Stainless } \\
\text { Steel } 309\end{array}$} & \multirow{3}{*}{0.5} & 5.182 \\
\hline & Tensile Yield Strength : $280 \mathrm{Mpa}$ & 20 & 56.221 & 0.0034462 & 4.9803 & 150.241 & 11.372422 & & & 10.4855 \\
\hline & Tensile Ultimate Strength: $310 \mathrm{Mpa}$ & 30 & 84.332 & 0.0051693 & 3.3202 & 184.417 & 17.139782 & & & 15.9 \\
\hline & Stainless Steel 309 & 10 & 28.179 & 0.0006622 & 7.346 & 105.547 & 5.63569 & & & 4.5323 \\
\hline & Tensile Yield Strength : $207 \mathrm{Mpa}$ & 20 & 56.357 & 0.0013244 & 3.673 & 150.241 & 11.372422 & & 1 & 9.13293 \\
\hline & Tensile Ultimate : $586 \mathrm{Mpa}$ & 30 & 84.536 & 0.0019866 & 2.4487 & 184.417 & 17.139782 & & & 13.5512 \\
\hline \multirow{6}{*}{2} & Aluminum Alloy (5059-H321) & 10 & 37.632 & 0.0018184 & 7.4405 & 106.94818 & 5.78393 & \multirow{6}{*}{$\begin{array}{l}\text { 2- For } \\
\text { Aluminu } \\
\mathrm{m} \quad \text { Alloy } \\
(5059- \\
\text { H321) }\end{array}$} & \multirow{3}{*}{0.5} & 5.5878 \\
\hline & Tensile Yield Strength : 280Mpa & 20 & 75.263 & 0.0036368 & 3.7203 & 151.83174 & 11.6598 & & & 11.612 \\
\hline & Tensile Ultimate Strength: $310 \mathrm{Mpa}$ & 30 & 112.9 & 0.0054552 & 2.4802 & 186.3584 & 17.56669 & & & 16.6771 \\
\hline & Aluminum Alloy (5059-H321) & 10 & 37.632 & 0.0018184 & 7.4405 & 106.94818 & 5.78393 & & \multirow{3}{*}{1} & 4.54122 \\
\hline & Tensile Yield Strength : 280Mpa & 20 & 75.263 & 0.0036368 & 3.7203 & 151.83174 & 11.6598 & & & 9.15594 \\
\hline & Tensile Ultimate Strength: $310 \mathrm{Mpa}$ & 30 & 112.9 & 0.0054552 & 2.4802 & 186.3584 & 17.56669 & & & 13.7726 \\
\hline \multirow{6}{*}{3} & Aluminum Alloy (5059-H321) & 10 & 49.052 & 0.0028782 & 5.7083 & 121.92809 & 7.47761 & \multirow{6}{*}{$\begin{array}{l}\text { 3- For } \\
\text { Aluminu } \\
\mathrm{m} \quad \text { Alloy } \\
\text { (5059- } \\
\text { H321) }\end{array}$} & \multirow{3}{*}{0.5} & 7.11 \\
\hline & Tensile Yield Strength : $280 \mathrm{Mpa}$ & 20 & 98.103 & 0.0057563 & 2.8541 & 173.17232 & 15.0833 & & & 14.5495 \\
\hline & Tensile Ultimate Strength: $310 \mathrm{Mpa}$ & 30 & 147.15 & 0.0086345 & 1.9028 & 212.60106 & 22.7732 & & & 22.7405 \\
\hline & Aluminum Alloy (5059-H321) & 10 & 49.052 & 0.0028782 & 5.7083 & 121.92809 & 7.47761 & & \multirow{3}{*}{1} & 5.307 \\
\hline & Tensile Yield Strength : $280 \mathrm{Mpa}$ & 20 & 98.103 & 0.0057563 & 2.8541 & 173.17232 & 15.0833 & & & 10.8633 \\
\hline & Tensile Ultimate Strength: $310 \mathrm{Mpa}$ & 30 & 147.15 & 0.0086345 & 1.9028 & 212.60106 & 22.7732 & & & 16.6122 \\
\hline \multirow{6}{*}{4} & Aluminum Alloy (5059-H321) & 10 & 49.024 & 0.002879 & 5.7115 & 121.592 & 7.41739 & \multirow{6}{*}{$\begin{array}{l}\text { 4- For } \\
\text { Aluminu } \\
\mathrm{m} \text { Alloy } \\
(5059- \\
\text { H321) }\end{array}$} & \multirow{3}{*}{0.5} & 6.8786 \\
\hline & Tensile Yield Strength : $280 \mathrm{Mpa}$ & 20 & 98.048 & 0.0057581 & 2.8557 & 173.006 & 15.0129 & & & 13.6604 \\
\hline & Tensile Ultimate Strength: 310Mpa & 30 & 147.07 & 0.0086371 & 1.9038 & 212.585 & 22.6648 & & & 20.9219 \\
\hline & Aluminum Alloy (5059-H321) & 10 & 49.024 & 0.002879 & 5.7115 & 121.592 & 7.41739 & & \multirow{3}{*}{1} & 5.15207 \\
\hline & Tensile Yield Strength : $280 \mathrm{Mpa}$ & 20 & 98.048 & 0.0057581 & 2.8557 & 173.006 & 15.0129 & & & 10.2922 \\
\hline & Tensile Ultimate Strength: $310 \mathrm{Mpa}$ & 30 & 147.07 & 0.0086371 & 1.9038 & 212.585 & 22.6648 & & & 16.1263 \\
\hline \multirow{6}{*}{5} & Aluminum Alloy (5059-H321) & 10 & 39.063 & 0.0010167 & 6.4 & 136.118 & 9.2608 & \multirow{6}{*}{$\begin{array}{l}\text { 5- For } \\
\text { Aluminu } \\
\mathrm{m} \quad \text { Alloy } \\
(5059- \\
\text { H321) }\end{array}$} & \multirow{3}{*}{0.5} & 8.256 \\
\hline & Tensile Yield Strength : $280 \mathrm{Mpa}$ & 20 & 98.048 & 0.0020334 & 3.2 & 193.005 & 18.6157 & & & 16.6854 \\
\hline & Tensile Ultimate Strength: $310 \mathrm{Mpa}$ & 30 & 117.19 & 0.0030501 & 2.1333 & 236.709 & 27.9987 & & & 25.1919 \\
\hline & Aluminum Alloy (5059-H321) & 10 & 39.063 & 0.0010167 & 6.4 & 136.118 & 9.2608 & & & 8.01619 \\
\hline & Tensile Yield Strength : $280 \mathrm{Mpa}$ & 20 & 98.048 & 0.0020334 & 3.2 & 193.005 & 18.6157 & & 1 & 16.0126 \\
\hline & Tensile Ultimate Strength: 310Mpa & 30 & 117.19 & 0.0030501 & 2.1333 & 236.709 & 27.9987 & & & 24.1496 \\
\hline
\end{tabular}




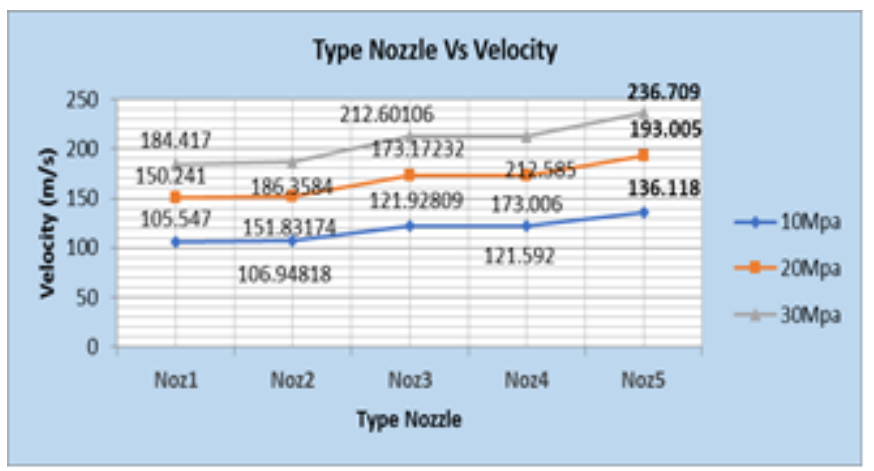

Fig. 7: Comparison of average outlet velocity of five designs of nozzle at $10 \mathrm{MPa}, 20 \mathrm{MPa}$ and $30 \mathrm{MPa}$

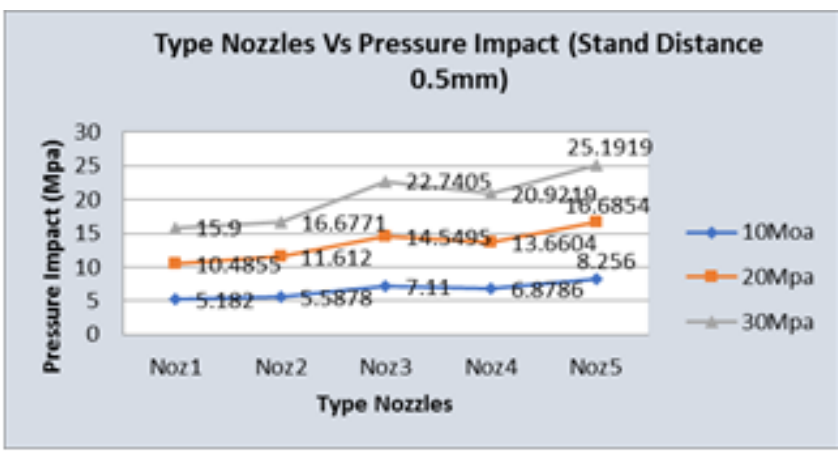

Fig. 8: Comparison of pressure impact of five designs of nozzle at $10 \mathrm{MPa}, 20 \mathrm{MPa}$ and $30 \mathrm{MPa}$

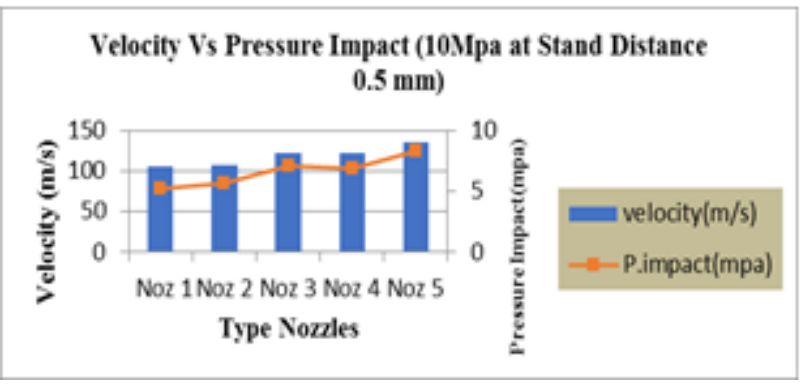

Fig. 9: Impact pressure and average outlet velocity at stand distance of $0.5 \mathrm{~mm}$

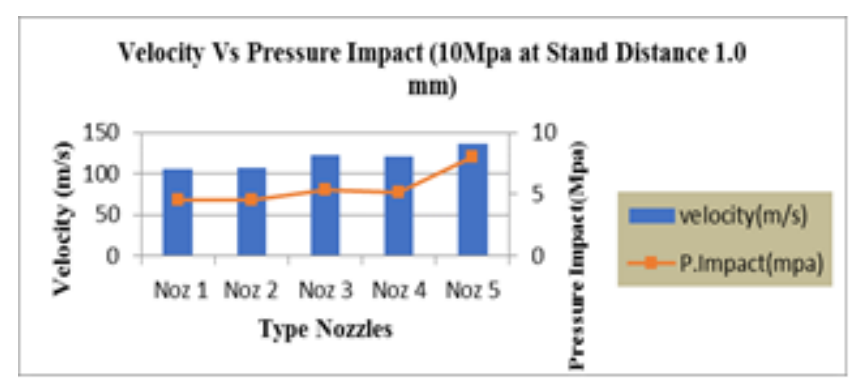

Fig. 10: Impact pressure and average outlet velocity at stand distance of $1.0 \mathrm{~mm}$

\section{CONCLUSION}

The factor of safety, impact pressure and average outlet velocity of five designs of nozzle were investigated. It was found that the Factor of Safety decreases to 1.9 as the inlet pressure increases. However, this is still acceptable for nozzle design. The impact pressure is affected by stand distance where slight reduction was observed at a lower inlet pressure. For the average outlet velocity, the ratio of velocity produced by $30 \mathrm{MPa}$ is about 1.7 times higher than the one with $10 \mathrm{MPa}$. There is no reduction in average outlet velocity was observed between $0.5 \mathrm{~mm}$ and $1.0 \mathrm{~mm}$ stand distance. The findings obtained from this work is applicable to the design of pure water jet cutting machine.

\section{REFERENCES}

1 M. A. I. Baharudin, Portable pure water jet machine. 2013.

2 B. Yuan, Y. Kang, X. F. Yang, Z. L. Fang, and D. Li, "Numerical investigation on high-pressure convergent nozzle by comparative and statistical analysis method," In IOP Conference Series: Earth and Environmental Science, 15(7), 2012, pp. 1-8.

3 D. Wright, J. Wolgamott, and G. Zink, "Waterjet nozzle material types," WJTA American Waterjet Conference, 2003, pp. 17-19.

\section{AUTHORS PROFILE}

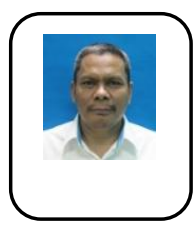

RazaliAbidin completed his Ph.D in Mechanica Engineering in National University of Malaysia, M.Eng and his first degree in UniversitiTeknologi Malaysia. His research interest in Mechanical Product Design, Advanced Manufacturing Technology, Weaponary System. Currently he is Associate Professor in Faculty of Engineering, National Defense University of Malaysia.

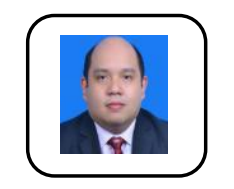

MohamadAsmidzamAhamat completed his MEng and $\mathrm{PhD}$ both from the University of Bristol, UK, respectively. His research interest on Adsorption Refrigeration, Thermoelectric Module Applications, Heat and Mass Transfer, Flow Visualisation and Fluidization. Currently he is Senior Lecturer in University Kuala Lumpur, Malaysia France Institute.

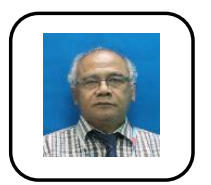

Tarmizi Ahmad is a lecturer with the Faculty of Engineering, National Defense University of Malaysia. His research interests are Light Aircraft Design, Flight Testing, and Aircraft Maintenance Technology.

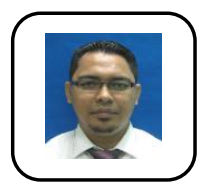

HafiziNordinis a Research Officer in Faculty of Engineering. Currently he is a PhD student in Mechanical Product Design and Advanced Manufacturing Technology field. He also served as the Research Fellow for Centre for Defence Research and Technology (CODRAT).

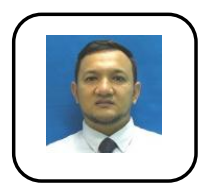

Wan Hanif Wan Yaacob is a Research Officer in Faculty of Defence, Science and Technology. Currently he is also pursuing his $\mathrm{PhD}$ student in Mechanical Product Design and Advanced Manufacturing Technology field. He also served as the Research Fellow for Centre for Defence Research and Technology (CODRAT) 